\title{
MIR18A Pre-miRNA
}

National Cancer Institute

\section{Source}

National Cancer Institute. MIR18A Pre-miRNA. NCI Thesaurus. Code C82707.

MIR18A pre-miRNA is an oligonucleotide that is encoded by the human MIR18A gene and has a role in the regulation of gene expression. 